\title{
THE DYNAMICS OF RELATION BETWEEN THE STATE AND LOCAL RELIGIONS IN INDONESIA: BETWEEN IDEALISM AND REALITY
}

\author{
Adib 'Aunillah Fasya, Alif Al Hilal Ahmad, \\ Muhammad Lukman Arifianto and Zainurrakhmah \\ Gadjah Mada University
}

\begin{abstract}
This paper, in general, discusses the relation between the state and local religions in Indonesia. There is no doubt that Indonesia is one of the countries which has local religions or beliefs with a considerable number of followers, so that the state needs to protect of the followers of these religions. However, after the passing of the government regulation on the recognition of particular official religions in the country, various issues related to formally unrecognized religions began to emerge, including discrimination by the government, especially in administrative matters, as well as social discrimination by the community that denies their existence. Various methods are used by the state to minimize the discriminatory attitudes by issuing multiple regulations and policies, but still it is not considered satisfactory to satisfy all parties, especially those who have been discriminated.
\end{abstract}

Keywords: Religion Local, State, Faith, Religious Freedom

\section{INTRODUCTION}

The democratic system in Indonesia is different from that of the West because Indonesia adheres to the Pancasila system of democracy (Sartika, 2012: 240). One of the most important points in the system of Pancasila Democracy is the appreciation of Human Rights (HAM) as well as legal and social protection on the minorities. Therefore, ideally the state through the government should be able to protect and guarantee the rights of all citizens with no exception, including the right to religious freedom. The freedom of religion and belief is the constitutional right of the Indonesian citizens that is generally approved by all parties (Vermonte and Basuki, 2012: 36).

Freedom of religion has become an important issue that sometimes leads to polemic in activities of social life, politics, and economy in Indonesia, especially in recent years (Vermonte and Basuki, 2012: 27). In the 1945 Constitution of the Republic of Indonesia Article 29 (2), it is stated that the state guarantees the independence of each resident to profess their own religion and to worship 
according to his/her own religion or belief. The Article of the Constitution implies that the state has a vital role to protect every citizen in performing worship or religious rituals based on their own belief. As a result, the state is expected to protect all citizens without any tendency (especially religious tendencies), that will create a conducive atmosphere, as well as quiet, safe, and peaceful religious life.

Although the state constitution guarantees religious freedom of its citizens, in reality the freedom of citizens in religion as stipulated in the 1945 Constitution, Article 29 paragraph 2 was 'weakened' by the explanation in Article 1 of Presidential Decree No. 1 / PNPS / 1965 concerning the Prevention and Misuse and / or blasphemy. The explanation of Article 1 of the regulation is that religions embraced by the people in Indonesia are those officially recognized by the state, i.e. Islam, Christianity, Catholicism, Hinduism, Buddhism, and Confucianism (after its recognition in 2001).

It certainly raises debate among the people, i.e. the birth of a dichotomy between 'recognized' and 'unrecognized' religions, majority and minority religions, global and local religions, primitive and modern religion, etc. (Hasse et al ., 2011: 181). Furthermore, it also indirectly implies that only religions recognized by the state alone can get facilities from the state, both in administrative matters and in the performance of religious worship. This also means that religions that do not get the recognition from the government of course will have difficulties in some aspects such as paperwork, constitution, freedom of worship, etc., because they are considered "unofficial". There is a possibility, too, that the Presidential Regulation can be used as a strong legitimacy for the "hard-line" groups to suppress the minority that is considered to tarnish the official religions (Vermonte and Basuki, 2012: 33).

When talking about the history, long before the Republic of Indonesia was founded and proclaimed, the existing beliefs (religions) of local or traditional spread almost all over the archipelago outside the six religions now recognized by the state, including the Khalik religion of the Wana, the Kaharingan religion of Dayak Pitap, the Patuntung of the Tanah Toa Kajang, Islam Wetu telu in Lombok, etc. Thus, with the issuance of the International Covenant on Civil and Political Rights, the Government policy in the form of Presidential Decree No.1/1965 regarding the Prevention of Blasphemy is considered a serious problem, since restrictions on the recognition of the religions by the state has indirectly caused restrictions on the rights of citizens in choosing their own religion, especially the local religions in Indonesia which had already existed before the "official" religions came.

Even though it is explicitly stated in the regulation that religions other than the 
six officially recognized above are not prohibited by the state and receive state guarantees in full as provided by Article 29 Paragraph 2 of the 1945 Constitution, such restrictions on the number of religions recognized are considered against the nature of the state in the system of democracy while ensuring the right of every citizen to profess any religion they embrace. In addition, although the local religions are not banned and but in fact guaranteed by the state, gradually these restrictions potentially provide a discourse in society that religions other than official religions established by the government through the Ministry of Religious Affairs are not authorized or not considered a religion, so that it gave birth to two camps: one that recognizes local religions and the other that denies the existence of local religions because they are considered to degrade or "contaminate" the official religions. Therefore, the state is currently faced with the policies and their implementation in order to accommodate the existence of the local religions.

Through the method of literature study on books, scientific journals, news, etc., this research is expected to map out the problems of the relation between the state and local religions in Indonesia comprehensively, and to find some solutions expected to improve it. The library research was conducted through reading, observing and analyzing books, research reports, state or government regulations, including laws, as well as scientific journals related to the relation between the state and local beliefs in Indonesia. The results of the research are presented within the framework of a descriptive-analytic paper.

\section{THE EXISTENCE OF LOCAL OF RELIGIONS AND RELIGIUS FREEDOM}

In Indonesia, the definition and views related to freedom of religion and beliefs are still limited to what is regarded as the only official religions, or religions recognized by the state. Conceptually and philosophically to determine the official and unofficial religions can be considered a form of intolerance and discrimination. The ruling of religions by the state or even by society itself is a major element in the invasion of religious freedom, i.e. freedom of conscience (Vermonte and Basuki, 2012: 36).

Speaking of the local religions in Indonesia, it would require a starting point of the definition of religion in the country itself. During this time, the government tends not to categorize the indigenous Indonesian beliefs as a religion, or in other words they do not qualify to be called a religion. In 1978, local religions in Indonesia were incorporated into the Ministry of Culture because they were regarded as a spiritual culture not religion. ${ }^{2}$ Therefore, the

2 See: http://www.bbc.com/indonesia/laporan_khusus/2011/04/110405_agamasatu.shtml. 
definition of religion, especially in Indonesia needs to be reviewed.

If we take a look at the Great Dictionary of the Indonesian Language, religion is defined as a doctrine or system that governs faith and belief in God Almighty, way of worship, and rules related to relationships between humans, between humans and the environment (Language Center, 2008). However, none of the legislations defines what religion is (Rosyid, 2015: 17). Even to this day, there is still an ongoing debate among academics and stakeholders about a standard definition of religion.

The lack of clarity about the standard definition of religion until now affects the government itself. As reported by Tempo (Feb 25, 2015) Lukman Hakim Saifuddin, Minister of Religious Affairs of the Republic of Indonesia said that the government is currently incompetent in managing conflicts involving religious matters because the regulations governing the definition of religion and protection to every religious community are considered insufficient.

In general, the concept of the term 'religion' in Indonesia has the same meaning as 'religie' or 'godsdients' of the Dutch language, 'religion' in English and 'din' in Arabic. The term religion is derived from the Sanskrit word whose meaning indicates the existence of human belief based on the revelation of God (Hadikusuma, 1993: 16). According to Picard and Madinier (2011: xi), the concept of religion in Indonesia is the union between the Christian view as a global religion and the Islamic understanding of the prerequisites of a true religion, which requires it to have prophets, a holy book, and belief in one God (monotheism).

In this context, the so-called religion, as set forth by the Department of Religious Affairs and put forward by Picard and Madinier, is something that must come from God through revelation, brought by the Prophet, written in scripture, containing rules of behavior, laws, and orderly way of worship (Burhani, 2012: 47). The definition is still not yet right and does not represent religion as a whole, particularly local religions in Indonesia. Basically, religion is the fulfillment of worship and faith, so it is a matter between each individual and God with regard to one's worship and faith (Majid, 1997: 3). Therefore, the impact on the local religious followers is that they have to choose to embrace one of the religions set by the government (Picard and Madinier 2011: xii)

When viewed from the creation of the concept of religion above, it can be concluded that a basic concept of religion in Indonesia requires four things, i.e, God as the origin of the religion, a prophet as the messenger of religious teachings, a holy book as religious guidelines, and standard procedures for worship. Thus, local beliefs such as Kaharingan, Aluk To Dolo, Sapto Dharmo, 
Kejawen, Tolotang, and others cannot be categorized as religions because they do not have a holy book or a prophet or a theological concept equivalent to Islam or Christian (Burhani, 2012: 48).

Local religion is a true historical fact undisputed by anyone at any time. Unfortunately, through the path of history the fate of local religions is not entirely promising. The political pendulum and the state policies are not fully capable of maintaining these local beliefs, which essentially are rich with local wisdom. Administratively, a local religion or belief is managed under the Ministry of Education and Culture. There are approximately 246 local religious organizations put under the MInistry. The number of these organizations is constantly changing, some of them are dispersed, others banned by the government (Lindholm et al., 2010: 691). The local belief with the most followers is the Buhun in West Java. The number of adherents reached 100 thousand or $25 \%$ of the total number of followers of a traditional belief as a whole. Other religions include the Sunda Wiwitan in Kuningan, West Java; Kejawen in Central Java; Parmalim in North Sumatra; Kaharingan in Kalimantan; Tonaas Walian in Minahasa North Sulawesi; Tolotang in South Sulawesi; Aluk Todolo in Toraja; Wetu telu in Lombok West Nusa Tenggara; Kapribaden in several areas in Java; and Naurus on Seram Island in Maluku Province.

Despite the fact that the followers of local religions now still exist in some regions in Indonesia and still adhere to the teachings of their religions, of course they always face challenges. One of the challenges faced by these communities is to maintain their identity and religious teachings both in terms of quantity and quality, as well as a challenge to exist in the midst of social, economic, political conditions that continue to change (Mufid, 2011:3).

\section{RELATION BETWEEN THE STATE AND LOCAL RELIGIONS}

Indonesia is an example of a unique case study in the relation between religion and the state. Even though the country adopt neither theocracy nor secularism, it formally through the Ministry of Religious determines what is referred to as a "religion" and makes people feel the need to affiliate with one of these religions (Picard and Madinier, 2011: i). One way that people feel the need to embrace the religion officially recognized by the government is to issue regulations related to religious affairs. Thus, people who initially did not embrace the official religion now began to abandon their indigenous religion or belief and convert to the official religion for the sake of receiving facilities, especially in matters of administration. 
In regulating all aspects of community life, especially in the aspect of the right to embrace a certain religion, it is undeniable that the country is indeed ideally in need of creating and validating a clear rule or law as its legal basis. As in the case of freedom of religion set in the Constitution of 1945, Article 29 paragraph 2, which states that the state guarantees the independence of each citizen to profess their own religion and to worship according to his/her own religion or belief. In addition, Law No. 39/1999 on Human Rights Article 22 Paragraph 1 and 2, it is also mentioned that everyone is free to embrace their religion and the state guarantees the freedom of every person to embrace a religion. Both of these rules imply that every individual is free to embrace and worship according to a religion or belief he/she believes as long as it does not interfere with the rights of other individuals and public order.

Nevertheless, in fact as discussed in the introduction, religious freedom has been weakened by the Presidential Decree No. 1/PNPS/1965, which only recognizes six religions, i.e. Islam, Christianity, Catholicism, Hindu, Buddha, and Confucian ism (recognized in 2001). As a result, it has caused the followers of religions other than the six recognized ones to feel marginalized.

In addition to matters related to "recognized" and "unrecognized" by the state as described in the previous paragraph, the relation between the state and local religions can be traced through government policies concerning Demographic Administration, i.e. Law No. 23/2006. As a guide to the implementation of the Law, the Government also issued Government Regulation (PP) No 37/2007. In Chapter VI, Article 64 paragraph (2) of Law No.23/2006 it is stated that information on religion for the people whose religion is not recognized as a religion, based on the provisions of legislation, it is stated on (the ID card ), but still recorded in the database of population (Mufid, 2012: 4). Although the policy of Law No. 23/2006 has been changed into Law No. 24/2013, an explanation of the religion column remains unchanged. Even still recorded in the database of the state population, the empty column of religion in one's identity card would rise to polemics in the community. The empty column for information on religion today still cause difficulties to local religious followers in the affairs of the state administration, such as marriage, birth certificate issuance, etc.

In addition, as a result of the Presidential Decree No.1/PNPS/1965, which had been enacted through Law No. 5/1969, some people proposed to review the regulation at the Constitutional Court. It drew a lot of pros and cons. The Constitutional Court eventually rejected the judicial review on grounds that if the judicial review of Law No. 1/PNPS 1965 about the abuse and/or blasphemy was granted, it was feared that there will be an absence of regulations related 
to the affairs of blasphemy and might trigger horizontal conflicts, social disorder, and chaos in society. It must be recognized that the rules concerning blasphemy is a dilemma. On the one hand, if there is no such a rule, then we might be faced with anarchy, people can do as they please, creating a new religion or cult according to their own will, but on the other hand if this rule is applied, the people who do not recognize the existence of certain religions or sects would use the rules to make judgments against minority groups that are considered "unofficial".

In the path of history of religion in Indonesia, it must be admitted that there is still tension that continues until today between people who believe in local (traditional) religions and those who reject the concept of local religions. The local religious followers insist that their beliefs are qualified to be a religion, while those who disagree found them unqualified to be called a religion in Indonesia (as described above). The tension ultimately played the role in the construction of concept of religion in Indonesia (Picard and Madinier, 2011: i). Therefore, needless to say that the construction of the concept of religion in this country is not purely derived from the spirit of the theology, but greatly influenced political affairs, in this case the influence of the colonial system.

With regard to the blank religion column in the National Identity Card as stipulated in Law No. 24/2013, it has been considered a positive development for religious freedom in Indonesia, at least compared to previous decades (Cholil, et al. 2010: 65). In fact, it is also considered much better than forcing the local religious followers to embrace one of the six officially recognized religions. However, some local religious followers in several regions finally affiliated or merged with the official religions as an attempt to obtain administrative facilities and in order to avoid social discrimination.

These six official religions that have been recognized by the government should remain protected by the state. Yet, outside the six religions, the state should also remain aware of the existence of local beliefs and guaranteed their rights even though the name is not listed on the identity card. Thus, every citizen shall not worry when performing their religious practices and not lose their religious identity. In this case the state must play an active role to restore the notion circulating in the local community that local religions are a religion that must be abolished.

For example in the marital affairs, as stipulated in Article 81 of Government Regulation No. 37/2007, the marriage of followers of local religions can only be recorded if performed in the presence of local religious leaders whose organization is appointed. The organization must register with the related Ministry that fosters local religious organizations. Therefore, any local 
religion should create a local religious organization which can later facilitate the administrative relationship with the state or government.

Local religions is part of the local wisdom of the nation that should be preserved and managed properly. The management can be done through regulations that do not marginalize them, especially related to the official documents issued by the state. Local religious position under the Ministry of Education and Culture also deserves to be reviewed. The Ministry of Religious Affairs should move quickly to formulate and establish appropriate regulations to accommodate the presence of the local religions. Facilities, access, and respect for local religions also should not be restricted. On the other hand, the active participation of the followers of local religions is also needed, so that the religious relations in the country remain harmonious and secure.

\section{CONCLUSION}

Issues related to religion often trigger lengthy polemics, particularly related to religious minorities as well as local religions. The State a the maker of regulations is expected to be open to the reality of local religions scattered throughout the archipelago, which have existed even before Indonesia's independence. Policies, mainly related to official documents issued by the government should be reviewed. The sixth official religions in Indonesia today, i.e. Islam, Christianity, Catholicism, Hinduism, Buddhism, and Confucianism should be protected from blasphemy, but outside the six, local religions should also be protected.

Taking a closer look at these dynamics, however, the existence of a local religion or belief and its followers in Indonesia is the responsibility of the state. The State represented in this case by the local government should be responsible for the existence of local religions in its political region. The government should be present as a patron at the individual level, not merely in dealing with the concept. Therefore, there should also be new regulations to further improve the quality of services related to administrative matters for the local religions, both at the central and regional levels.

In the concept of democracy, each individual wishes their existence and belief to be recognized and acknowledged by the state. However, social and political conditions of the country has yet to give such possibility as issues related to the recognition of local religions to become official are still debated, so it is probably necessary to have a forum with certain authority to reform the handling of religious affairs in Indonesia so as to gradually eliminate discrimination against local religions. 
As a matter of fact, the majority of the followers of local religions do not require or demand official recognition from the state. Yet, the Indonesian government at the moment is still "selective" in its management of the existence of religions, especially the local religions, Non Governmental Organizations (NGOs) concerned about the problem of the local religions in Indonesia and local religion organizations themselves are expected to play an active role in an effort to fight for their rights, especially the right to receive equal treatment as the followers of the official religions and the right to embrace religions base on their conscience.

\section{REFERENCES}

Burhani, Ahmad Najib. 2012. "Tiga Problem Dasar dalam Perlindungan Agama-Agama Minoritas di Indonesia” dalam Jurnal MAARIF Vol. VII No. 1. Jakarta : MAARIF Institute for Culture and Humanity

Cholil, Suhadi (at al.) 2012. Annual Report on Religious Life in Indonesia 2009. Yogyakarta : Center for Religious and cross-Cultural Studies (CRCS), Sekolah Pascasarjana, Universitas Gadjah Mada

Fanani, Ahmad Fuad. 2012. "Agama, Hak-Hak Minoritas, dan Problem Perlindungan Negara" dalam Jurnal MAARIF Vol. VII No. 1. Jakarta : MAARIF Institute for Culture and Humanity

Hadikusuma, Hilman. 1993. Antropologi Agama Bagian I: Pendekatan Budaya terhadap Aliran Kepercayaan, Agama Hindu, Budha, Kong $\mathrm{Hu} C u$ di Indonesia. Bandung : PT. Citra Aditya Bakti

Hasse, J. (at al.). 2011. "Diskriminasi Negara Terhadap Agama di Indonesia : Studi atas Persoalan Posisi Hukum Towani Tolotang Pasca Pengakuan Agama Resmi” dalam Jurnal KAWISTARA Vol. 1 No. 2. Yogyakarta : Sekolah Pascasarjana-UGM

Lindholm (at al.). 2010. Kebebasan Beragama atau Berkeyakinan: Seberapa Jauh? Yogyakarta: Kanisius

Madjid, Nurcholish. 2007. Masyarakat Religius: Membumikan Nilai-nilai Islam Dalam Kehidupan Masyarakat, Jakarta: Paramadina Press

Mufid, Ahmad Syafi'I (ed.). 2012. Dinamika Perkembangan Sistem Kepercayaan Lokal di Indonesia. Jakarta : Badan Litbang dan Diklat Kementerian Agama RI

Picard, Michel dan Madinier, Remy (ed.). 2011. The Politics of Religion in Indonesia: Syncretism, Orthodoxy, and Religious Concention in Java and Bali. New York : Routledge Contemporary Southeast Asia Series

Rosyid, Moh. 2015. "Dampak Hukum Tidak Diakuinya Agama Lokal Oleh 
Negara: Studi Kasus pada Masyarakat Samin di Kudus Jawa Tengah”. Makalah Training Tingkat LanjutRule of Law dan Hak Asasi Manusia Bagi Dosen Hukum dan HAM. Yogyakarta : PUSHAM-Universitas Islam Indonesia

Sartika, Rika. 2012 "Strategi Pelembagaan Nilai-Nilai Pancasila dalam Mencegah Sikap Anarkis pada Budaya Demokrasi” dalam Prosiding Kongres Pancasila IV. Yogyakarta : Pusat Studi Pancasila, Universitas Gadjah Mada

Vermonte, Philips J. dan Basuki, Tobias. 2012. "Masalah Intoleransi, Toleransi, dan Kebebasan Beragama di Indonesia” dalam Jurnal MAARIF Vol. VII No. 1. Jakarta : MAARIF Institute for Culture and Humanity

\section{Undang-Undang dan Peraturan Pemerintah;}

Peraturan Presiden Republik Indonesia Nomor 1/PNPS/Tahun 1965

diunduh dari http:// www.kemenag.go.id pada 31 Oktober 2015 Undang-Undang Dasar Negara Republik Indonesia Tahun 1945 diunduh dari http://www.mahkamahkonstitusi.go.id pada 31 Okober 2015 Undang-Undang No. 39 Tahun 1999 tentang Hak Asasi Manusia diunduh dari http://www.komnasham.go.id pada 31 Oktober 2015 Undang-Undang No. 24 Tahun 2013 (Perubahan dari Undang-Undang No. 23 Tahun 2006) tentang Administrasi Kependudukan. diunduh dari http://www.mahkamahkonstitusi.go.id pada 31 Oktober 2015 